\title{
SKLADATEL JAN VIČAR A ANALÝZA JEHO FOLKLORNÍHO TRIPTYCHU PRO SMÍŠENÝ SBOR NA ČESKÉ, MORAVSKÉ A SLEZSKÉ LIDOVÉ TEXTY ŠIROKO DALEKO
}

Olomoucký rodák Jan Vičar (*1949) patří do skupiny komponujících hudebních teoretiků, historiků a pedagogů, jako byli či jsou např́klad vysokoškolští profesoři Karel Janeček, Zdeněk Blažek, Karel Risinger, Jaroslav Smolka, Miloš Štědroň nebo Vladimír Tichý. Také on je vysokoškolsky erudován v obou disciplínách - ve skladbě i v muzikologii. K tomu se ještě přidává charakteristický rys jeho osobnosti a činnosti: nesmírná širre jeho zájmů a zvláště hojnost vědeckých, uměleckých a organizačních aktivit.

Jan Vičar při studiu na střední všeobecně vzdělávací škole v Olomouci-Hejčíně v letech 1964 až 1967 zároveň navštěvoval olomouckou Lidovou konzervatoř, kde se učil hře na akordeon a na klarinet. Po maturitě studoval souběžně jednak na Filozofické fakultě Univerzity Palackého v Olomouci hudební výchovu a češtinu, jednak dálkově na ostravské konzervatoři hru na akordeon. Univerzitní i konzervatorní studia ukončil v roce 1972 . V př́pravě na skladatelskou dráhu pak pokračoval studiem kompozice na Janáčkově akademii múzických umění v Brně (u Zdeňka Zouhara, 1976-78) a - po přestupu - na Hudební fakultě Akademie múzických umění v Praze (u Jiř́ho Dvořáčka, 1979-81; absolvoval kantátou Křik), na což pak navázal postgraduálním kursem hudební teorie na HAMU u Karla Risingera (1981-83). Předtím však v roce 1974, jako mladý asistent na katedře hudební vědy a výchovy Filozofické fakulty UP, získal pod vedením profesora Roberta Smetany titul PhDr. na základě později vydané rigorózní práce Akordeon a jeho hudebni uplatnění. V polovině osmdesátých let přesídlil z Olomouce do Prahy, kde učil hudební estetice na pražské AMU a pracoval v časopise Hudební rozhledy. V roce 1985 získal hodnost kandidáta věd o umění (CSc.) po obhájení disertace Stylové tendence v díle Václava Trojana v Ústavu teorie a dějin umění ČSAV, docentem na HAMU byl jmenován v roce 1988. Začátkem devadesátých let se zasadil o znovuotevření studia hudební vědy na olomoucké Filozofické fakultě a stal se vedoucím katedry muzikologie. V roce 1995 se na své alma mater znovu habilitoval, a to na základě monografie Václav Trojan vydané v Pantonu; profesorem pro obor teorie a dějiny hudby se stal 1998 tamtéž. 
Během řady svých pracovních cest a delších zahraničních stáží proslovil řadu přednášek. Pobýval např́íklad v Berlíně, Římě, Bologni, Cambridge, Londýně, a zejména na univerzitách v USA, kde působil v akademickém roce 1998/1999 jako Fulbright scholar-in-residence a v roce 2005 jako profesor kompozice a hudební teorie na Birmingham-Southern College v Alabamě.

Jako muzikolog se začal hned po ukončení svých univerzitních studií badatelsky orientovat na hudební estetiku, hudební kritiku, teorii, dějiny a estetiku české hudby 20. století, dílo Leoše Janáčka a kritické edice hudby. Dosud vydal šest knih (včetně jedné vysokoškolské učebnice) a mnoho desítek studií a statí v odborných časopisech a sbornících. ${ }^{1}$ Hudební kritice se věnoval nejen teoreticky, ${ }^{2}$ ale zvláště vlastním kritickým sledováním hudebního života v Olomouci a v Praze. Napsal přes 200 recenzí, hlavně do Hudebnich rozhledů, časopisu, jehož byl v letech 1986-1989 šéfredaktorem.

Samostatnou kapitolou Vičarovy odborné činnosti je jeho vysokoškolské pedagogické působení. Vyučoval nebo vyučuje hudebně teoretické předměty, hudební estetiku, hudební kritiku a hudební popularizaci na Hudební a taneční fakultě pražské Akademie múzických umění a na Univerzitě Palackého v Olomouci, je školitelem doktorandů v oboru teorie a dějiny hudby a teorie hudební interpretace.

I když muzikologická práce téměř ve všech etapách Vičarovy tvůrčí kariéry převažovala, skladatelské tvorbě se po absolutoriu oboru skladba na HAMU ani v době největšího vytížení jinými úkoly nikdy nepřestal zcela věnovat. ${ }^{3}$ Jeho kompoziční dílo, v oblasti vokální (zvláště sborové), ale i orchestrální či komorní je charakteristické svým značně širokým žánrovým, stylovým i funkčním rozpětím. Hudební kritika dokonce s jistou nadsázkou označila Vičara pro jeho ,inklinace $k$ bezhraničnosti inspiračnich zdrojü" za ,hudebniho cestovatele “. ${ }^{4} \mathrm{~V}$ jeho kompozicích se objevují spontánní folklorní inspirace, které pramení z jeho moravanství, v četných písních a sborech pro děti (ale nejen tam) jsou výrazné jazzové názvuky (vždyt' Vičar jako pohotový pianista, dř́iv také hrával i v kapelách moderní populární hudbu), z jeho sdělné hudby často vyzařuje laskavý vtip a smysl pro humor, zároveň jsou však zde funkčně využívány též soudobé kompoziční techniky. Sám autor charakterizoval svou tvorbu jako př́klad postmodernistického pojetí hudební kompozice.

Významné postavení v jeho pozoruhodné, byt' neprríliš rozsáhlé tvorbě (vždyt' Vičar byl činný v mnoha dalších oblastech hudební kultury), zaujímají sborové

1 Akordeon a jeho hudební uplatnění. Praha: Panton, 1981; Václav Trojan. Praha: Panton, 1989; Hudebni kritika a popularizace hudby (Praha, 1997), Finale. Učebnice počitačové notace (překlad a adaptace amerického originálu David Pogue: Finale. The Art of Music Notation. Vol. I, s Helenou Pavličíkovou a Martinem Voříškem, Praha, 1997), Hudebni estetika (s Romanem Dykastem, Praha, 1998), soubor esejů o české hudbě a estetice v angličtině Imprints: Essays on Czech Music and Aesthetics (Olomouc-Praha, 2005).

2 Srov. např. jeho výše uvedenou publikaci Hudební kritika a popularizace hudby.

3 Jan Vičar dosud zkomponoval více než šedesát opusů.

4 Viz např. kritika Miloše Pokory v Hudebnich rozhledech, 2009, roč. 62, č. 6, s. 17-18. 
kompozice. Nejprve to byly cykly pro dětský sbor komponované od osmdesátých let až do současnosti, např. Ahoj, moře!, Zpiváme si, Mišsovy pisničky, Ufo, ufo, ufoni a jiné písničky pro děti, Voda, voděnka; Co mi ještě zbylo ze Žáčka, O Káče a s Káčou, Hanýskovy pisničcky aj., tiskem většinou vydané nakladatelstvím MusicOl. V nich skladatel zužitkoval též své bohaté zkušenosti, které získal jako jeden z hlavních organizátorů a dramaturgů festivalu dětských sborů Svátky písní Olomouc i jako sbormistr Pěveckého sboru olomouckých učitelek (v letech 1975-1978).

V posledních letech některá naše špičková sborová tělesa provádějí s velkým úspěchem rovněž jeho kompozice pro smíšené, nebo ženské či mužské sbory. ${ }^{5}$ Ty byly vydány olomouckým univerzitním nakladatelstvím ve sbornících Smišené sbory (1998-2008), Ženské sbory (1998-2009) a Mužské sbory (2006-2011). ${ }^{6}$ Všechny tyto sborniky obsahovaly také jeho dosud nejúspěšnějši sborovou kompozici Gurale, která byla v roce 2006 napsána pro smíšený sbor a o rok později přepracována rovněž pro mužské a ženské event. i dětské těleso. $V$ těchto třech různých verzích byla tato kompozice dosud nastudována patnácti předními sborovými tělesy a dočkala se mnoha desítek provedení na koncertních a soutěžních pódiích v České republice i v zahraničí. ${ }^{7}$

Vedle sborových kompozic zaujímají významné postavení ve Vičarově dosavadní tvorbě i další skladby, jako jsou například písňový cyklus Japonský rok pro soprán, flétnu, klavír a piano préparé, Poučeni Šuruppakovo pro hlas a harfu, Čtyři písně na slova Jiřiho Žáčka, kantáta pro baryton, smíšený sbor a orchestr Křik na slova téhož básníka aj., ale i díla komorní a orchestrální. ${ }^{8}$

5 Vičar je například považován za „dvorního skladatele“ mužského vokálního souboru Gentlemen Singers.

V roce 2013 vydala UP další Vičarův rozsáhlý notový sborník Písně a melodramy (19772012), a Radioservis vydal jeho pátý kompaktní disk Ej, Janku! s nahrávkami sborových skladeb ovlivněných hudebním folklorem. CD obsahuje též skladby později zahrnuté do folklorního triptychu Široko, daleko.

$7 \quad$ Skladbu Gurale mají ve svém repertoáru Bonifantes (sbormistr Jan Míšek; vydáno na CD Bonifantes USA 2006), Jitro (Jiří Skopal), Gentlemen Singers (Richard Uhlíŕ; vydáno jako bonus v 3. edici CD Canto ergo sum), KOS Litomyšl (Milan Motl; vydáno na CD Gufo), Pueri gaudentes (Zdena Součková), Permoník Karviná (Eva Šeinerová; vydáno na CD $F a$ mous Czech Songs), Kühnův smíšený sbor (Marek Vorlíček), Ars voce Krnov (Kamil Trávníček), Cantica laetitia (Josef Surovík), VOSK Praha (Jan Zapletal), Omnibus Praha (Vít Novotný), Oktet Praha (Michal Hájek; vydáno na CD Oktet. Jsme nahraní), Smíšený sbor Hudební akademie v Bydgošti (Krzysztof Szydzisz), Musica Oeconomica Pragensis, Praha (Martina Spritová), Nona z Ústí nad Labem (Luboš Hána).

8 Uved'me třeba Smyčcový kvartet, Nonet o horách, dúbravách a valašskéj zemi, Sonátu pro flétnu a cembalo, Hudbu pro smyčce a tympány, symfonický obraz Cesta k slunci, Noční modlitbu, symfonické procesí pro velký orchestr Vivat universitas!, Tři pochody pro dr. Kabyla ve verzi pro velký dechový orchestr nebo pro žest'ové kvinteto, dvanáct skladeb pro klavír s charakteristickým názvem Přeludya, Hudbu pro Míšana pro žest'ové kvinteto, Pocta hudcům pro housle a violoncello (2006), Uspávanky pro housle/basklarinet a klavír či Piano-forte pro marimbu a taiko. 
Folklorní triptych pro smíšený sbor na české, moravské a slezské lidové texty Široko daleko vznikl v roce 2012 cyklickým spojením tří původně samostatných kusů (upravených pro smíšená, mužská a ženská sborová tělesa), kterými byly Vejr (2007), Daleko, široko (2011) a Gurale (2006). V témže roce byl pro potřeby polských sborů pořízen Izabelou Szulc překlad, a to na bázi slezského nářečí. ${ }^{9}$ Iniciátorem tohoto projektu byl polský sbormistr a organizátor poznaňských sborových festivalů Krzysztof Szydzisz.

Ačkoliv tedy autorovým prvotním záměrem nebyl cyklus, výsledný patnáctiminutový triptych Vejr - Daleko, široko - Gurale působí při koncertním provedení jako logicky skloubený celek. Má jasnou dramaturgickou linku, která využívá při celkové výstavbě zejména kontrastů $v$ jednotlivých složkách hudby, a to zvláště $\mathbf{v}$ kinetice (tempo a nárůst hybnosti v krajních, převážně rychlých částech), $\mathbf{v}$ sóničnosti (práce $\mathrm{s}$ témbrem vedoucí až $\mathrm{k}$ prostorovým efektům v prostředním sboru), ve volbě textů žertovných mateníkových písní z východních Čech - Nymburska, Chrudimska, Kameniček a ze severozápadních Litoměřic, dvou moravských táhlých písní z Vlčnova a od Příbora (původně zpívaných při žních), či „epické“ písně slezské s veselým zakončením (respektive písně goralské z východní části „českého“ Slezska, tj. Těšínska a Jablunkovska - ale též západoslovenských Kysuc a Oravy).$^{10}$ I nadále je přirozeně možné uvádět jednotlivé části cyklu samostatně, ostatně tak i vznikaly (a podtitul „folklorní triptych“ nese pouze verze pro smíšený sbor).

První sbor triptychu Vejr je vytvořen na podkladě zhudebnění několika písňových textů mateníkového typu, ${ }^{11}$ čtyřnásobným opakováním jednoduchého dvaatřicetitaktového melodicko-rytmického modelu $a a^{\prime} b b a a^{\prime}(6+6+4+4+6+6$ taktů), kde $a$ i $a^{\prime}$ mají čtyřtaktové předvětí v dvoučtvrtečním taktu a dvoutaktové závětí v taktu $3 / 4$

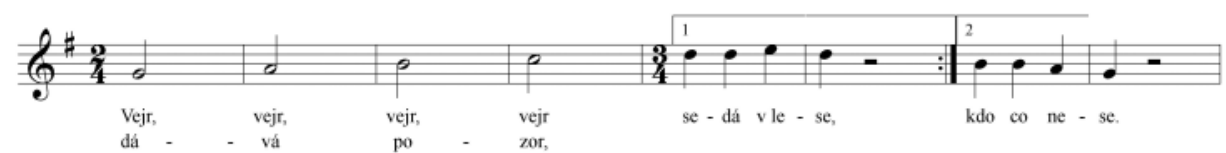

Př. 1 Stř́ídavé metrum mateníku Vejr.

9 VIČAR, Jan. Szeroko daleko. Tryptyk ludowy na chór mieszany. Przekład Izabela Szulc. 1. Puchacz - 2. Szeroko daleko - 3. Górale (2012).

10 Za scelovací prvek celého triptychu lze spatřovat i tóninový „plán“. Všechny tř̌ části cyklu ve verzi pro smíšený sbor jsou v G (dur), jen závěrečný úsek Gurale je v D dur. Volba tónin je dána i použitelnými rozsahy hlasů smíšeného sboru a úsilím o kontrastní využívání jeho nejhlubších a nejvyšších poloh.

11 Mateník je lidový tanec, při němž muzikanti po krátkých úsecích tanečních písní střídali metrum a tím pletli (mátli) tanečníky při tanci. 
a kde $b$ tvoří dvě $2 / 4$ dvoutaktí, která jsou opakována.

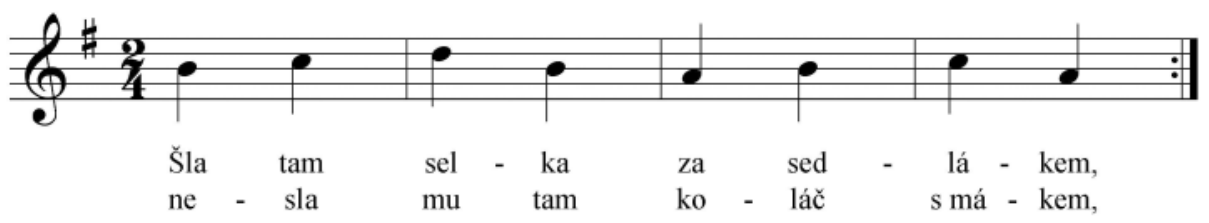

Př. 2 Část $b$.

Důležitou funkci má poměrně dlouhá introdukce (celkem 206 taktů), v první své části tvořená zaplňováním ticha výkřiky „,vejr“ (v osminásobně menší hybnosti, než je tomu před závěrem), po nichž nastupuje v mužských hlasech (2. část introdukce - takty 124-206) vzestupně-sestupná melodie s textem prvních dvou veršů. Je harmonizována akordy základních harmonických funkcí, které jsou však „zahuštěny“ prridanými tóny (sekundami a sextami; tyto zahuštěné akordy občas vytvoří i kvartový souzvuk). Celá plocha vytváŕí „tajemnou náladu“ zcela kontrastující s žertovným textem všech čtyř následujících dvaatřicetitaktových bloků s textem čtyř slok, které představují variačně zpracovaný mateník.

Mezi jednotlivé zhudebněné veršové sloky (jedná se o takty 207-238 [B], ${ }^{12}$ 271-302 [D], 335-386 [E], ${ }^{13} 405-436$ [F]) jsou vloženy jakési kontrastní plochy s dlouhými drženými tóny, glissandy imitujícími soví houkání a s tleskáním, svou tóničností často připomínající začátek kompozice. ${ }^{14}$ Teprve jeho závěr [G] - Coda s takty 437-478 - přináśí nový melodicko-rytmický (a textový) ${ }^{15}$ materiál v basových hlasech:

12 Tento dvaatřicetitaktový blok se opakuje jako [C], přičemž jeho části $a$ a $a^{\prime}$ si tleskáním sboristů ponechává základní mateníkovský rytmus a celý sbor zpívá části $b$ na text třetího a čtvrtého verše první sloky.

13 Zde jde o rozšíření původního dvaatřicetitaktového modelu $a a^{\prime} b \quad b a a^{\prime}$ na plochu o 52 taktech ve schématu: $a a^{\prime} a^{\prime \prime} a^{\prime}$ ( $4 \times 6$ taktů), $b b b b$ ( $4 \times 4$ takty), $a a^{\prime}$ ( $2 \times 6$ taktü). Opakované čtyřtaktí $b$ však není vždy ve stejném tvaru; poprvé je zpívají tenorové hlasy s textem 3 . verše 2 strofy, podruhé se sice $b \mathrm{v}$ tenorech opakuje, ale basy mají protimelodii na text 4 . verše 2. strofy, potřetí se k mužským hlasům připojují alty s textem 3. verše 1. strofy, a konečně nastupují i soprány s 4 . veršem 1 . strofy. Tato část [E] je vedena ve dvou střídajících se plochách (soprány a alty proti tenorovým a basovým hlasům), navíc doprovázených tleskajícím „protirytmem“ na druhou lehkou dobu. Jedná se tedy o jakési rytmické imitace, posunuté o jednu taktovou dobu.

14 Tyto plochy dlouhých držených tónů mužského sboru s označením catalettico (strnule) a s užitím parlandových výkřiků a glissandovým houkáním navozuje pocit strnulosti vejř́ího pohledu či snad vystihuje pohádkovou moudrost až bubáctví spojované se sovou nebo vejrem.

15 K stroficky utvářené skladbě (čtyři strofy o šesti osmislabičných trochejských verších) je připojena jako coda závěrečná píseň Já tak nebudu. Její hudební podoba vychází ze vzorné 


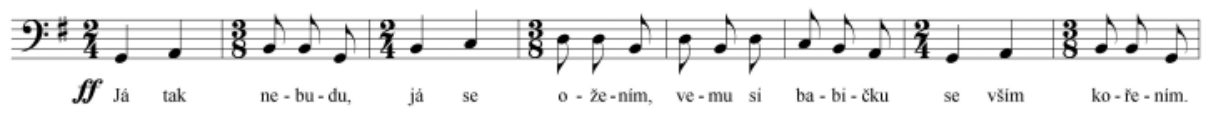

Př. 3 Rytmicko-melodický materiál v basových hlasech.

Druhý osmitaktový oddíl v tenorech a basech na text opakované první strofy je přeložen o kvartu výše (do subdominantní $C d u r$ ):

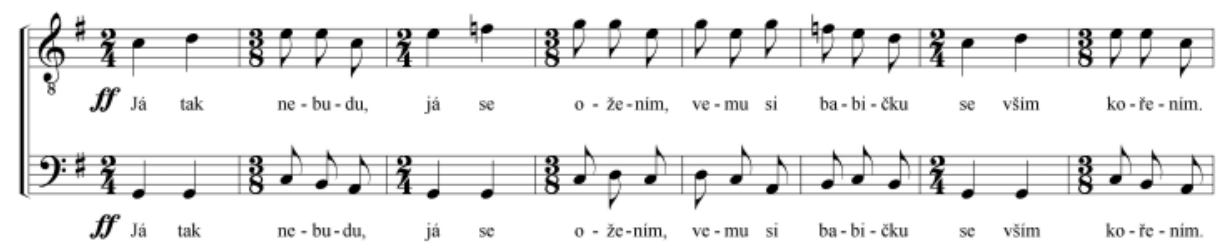

Př. 4 Vejr, takty 445-452.

Jedná se opět o mateníkový typ střídající takty $2 /{ }_{4} \mathrm{a} 3 / 8 \mathrm{v}$ členění, které vychází z prozodie lidového textu: repetice dvoutaktí $2 /{ }_{4} \mathrm{a} 3 / 8$, pak dva takty $3 /{ }_{8}$ a opět dva takty - jeden $2 / 4$ a jeden $3 / 8$, tedy $a$ a $b a$. Celá závěrečná píseň Já tak nebudu má strofickou podobu: $a, a^{\prime}, a, a^{\prime}(4 \mathrm{x} 8$ taktů + závěrečný diatonický cluster z tónů škály $C$ dur a s glissandem). Gradační coda je založená na postupném přidávání jednotlivých hlasů od basu po soprán $\mathrm{v}$ jednotném rytmu (homofonní sazbě) se sílící dynamikou a tleskáním v tutti. Závěr je tvořen clusterem $\mathrm{s}$ glissandem vrcholícím ve výkřik slova „vejr!“. I když se tato kompozice může jevit na základě rozboru jako poněkud „přetechnizovaná“, je-li interpretačně dobře zvládnutá, působí svou dominující metrorytmickou složkou (jež vychází z lidového textu) efektně, dynamicky a přitom velmi sdělně.

Textově i melodicky sourodý folklorní materiál, z něhož je vystavěna druhá část Daleko, široko, ${ }^{16}$ si vybral Jan Vičar ze Sušilovy sbírky Moravské lidové písněs nápěvy do textu vřaděnými. Jedná se o první sloky písní č. 1549 a 1553.

deklamace textu o třech čtyřveršových slokách (po dvou pětislabičných daktylotrochejských verších následuje šestislabičný daktylský verš a sloku uzavírá opět verš pětislabičný); první strofa této závěrečné písně se opakuje s osmitaktovou melodií v subdominantní tónině. Melodie s textem 2. strofy je opět v $G d u r$ a poslední sloka vybočuje opět do subdominantní tóniny.

16 Skladba má prostou velkou písňovou formu s introdukcí (takty 1-4) a codou 49-54) a díly A (5-22) - B (23-38) - A (39-48). 


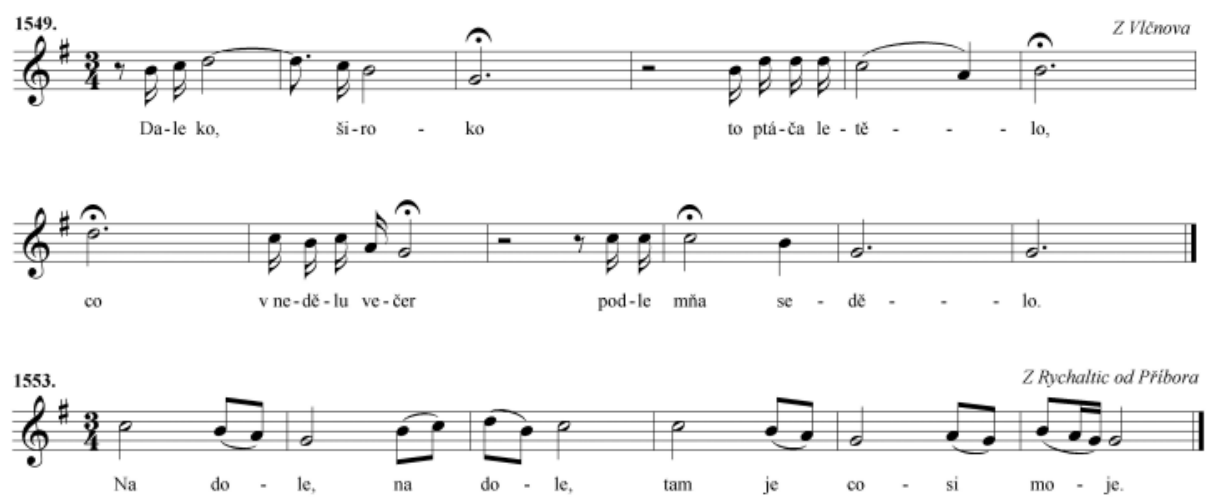

Př. 5 První sloky písní č. 1549 a 1553 ze Sušilovy sbírky.

Oba nápěvy jsou v Sušilově sbírce zapsané v $G d u r$, jejich tóninu ovšem Vičar přebírá dosti volně. ${ }^{17}$ Pohybuje se sice v modálním terénu „flexibilní diatoniky“ s centrem $G$, avšak osciluje vynecháním tercie nebo stř́́davým výskytem tónů $b$ či $h$ mezi frygickým modem a quasi ,hypoharmonickou“ c moll (resp. hypoaiolskou), nebot' využívá řady tónů $g-a s-h / b /-c-d-e s-f$. Tím zároveň pracuje s bitonalitou - současným zazníváním tónin $G$ dur a As dur jako dominanty k Des $d u r$ - a tak navozuje pocit velkého prostoru.
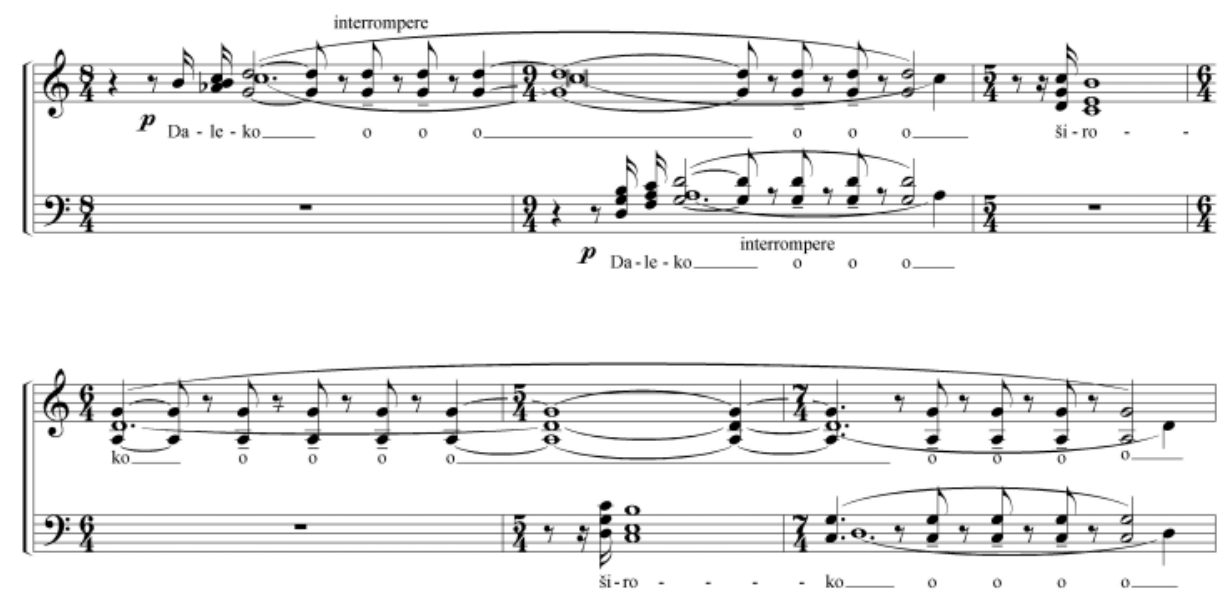

Př. 6 Jan Vičar, Daleko, široko, takty 5-10.

17 Verze pro smíšený sbor využívá diatonickou škálu od $g$, avšak jiné verze pro mužský a dětský/ženský sbor jsou transponované o velkou sekundu výše (in $A$ ). Také celkový počet taktů se u obou verzí liší; verze pro smíšený sbor má o dva takty více, nebot' závěr dílu $B$ je rozšířen o jeden $5 / 8$ a jeden $2 / 4$ takt. 
Ženské sopránové hlasy nastupují s textem „daleko“ v unisonu na tónu $h^{l}$ vzestupnou melodií lidové písně, zatímco alty sestupují volnou imitací (echem) v protipohybu ke $g^{l}$ přes charakteristický frygický interval malé sekundy s textem „široko“. Dospívají do intervalu čisté kvinty (mezi soprány a alty) znějící nejprve přes 15 a pak i 18 taktových dob a zpívanou na poslední samohlásku obou slov. $\mathrm{S}$ taktovým opožděním nastupují imitačním způsobem hlasy mužské, které spolu s přeznívajícími ženskými hlasy vytvářejí tonálně neurčité souzvuky čistých kvart. ${ }^{18}$

Těmto šesti taktům ovšem předchází krátký úvod vyznačující se stylizací jediného tónu (dominantního $d$ ) v oktávových transpozicích, navozující jistou tonální neurčitost celé skladby, zakotvené ovšem in $G .{ }^{19}$ Otevřený prostor volné přírody, v němž tyto táhlé písně zaznívaly, je u Vičara podtržen stř́́dáním taktů při velmi pomalém tempu ${ }^{20}(d=60)$, avšak s často se měnící hybností. Volně pojatá rytmická složka a „vypsané koruny“ způsobily, že ve čtyřiapadesátitaktové kompozici se vystřídají takty $2 / 4,3 / 4, \mathrm{C}, 5 / 4,6 / 4,7 / 4,8 / 4,9 / 4,10 / 4$ a po jednom $5 / 8$ a dvou $9 / 8$ a třech taktech $4 / 2$ - celkem 39 krát. $^{21}$

V taktech 11-15 zazní celý text první strofy písně, od první části druhého verše „to ptáče“ (takt 13) drobený rytmickými imitacemi (opožděné nástupy ženských a mužských hlasů), čímž se zvyšuje hybnost v celém úseku. Charakteristické je rovněž „rozostření“ zvukového zbarvení celé plochy. Po určitém zastavení pohybu v sudých taktech 14, 16 a 18 (zahuštěné souzvuky vyznívající jako diatonické clustery) a opět zvýšené hybnosti v lichých taktech, se v závěru tohoto úseku skladby, který je vytvořen z materiálu první písně, hudební proud zklidňuje v $G$ dur (takt 24).

Text a melodické názvuky druhé písně tvoří materiál pro poněkud kontrastní střední díl (takty 23-38). Napojení druhé písně je zcela nenásilné; vždyt' melodický závěr písně první s textem „podle mňa sedělo“ je téměř totožný se začátkem melodie druhé písně. Ovšem určitý rozdíl ${ }^{22}$ mezi díly $\mathrm{A}$ a $\mathrm{B}$ je patrný zvláště v užívání souzvuků tvořených většinou čistými kvartami ${ }^{23}$ na dlouhých prvních

18 Ve druhém trrítaktí zní souzvuky dvou čistých kvart v ženských hlasech dokonce v trvání 18 taktových (čtvrt'ových) dob.

19 Tón $d$, který je dominantou k centru $G$, je „rozostřován“ ozdobováním malými horními a spodními sekundami či současně zaznívajícími citlivými tóny. Tento sónický efekt je v celé skladbě užit vícekrát.

20 Tardissimo - co nejpomaleji, ovšem místy hybně až zajíkavě, přerušovaně.

21 Celkových 310 čítacích dob v rámci různých 54 taktů skladby při neměnném tempu (bez přirozené agogiky), kde $d=60$ (a trvá tedy jednu sekundu) dává duratu 5‘10“. Studiová rozhlasová nahrávka Martinů Voices se sbormistrem Lukášem Vasilkem pořízená v prosinci 2012 trvá 5‘29“.

22 Přitom pomíjíme, že skladatel v předvětí rozšíríl půdorys lidové písně zapsané v šesti taktech vložením opakování prvního trojtaktí (verše textu) o kvartu výše a samozřejmě učinil také velmi drobné rytmické změny, což má vliv na obměny taktového označení $(2 / 4$, v závětí pak $9 / 8$ a 5/8).

23 Jde o kvartové akordy, které ovšem posazeny do pěveckého rozsahu pěveckého sborového nabývají místy podoby „Zahuštěných akordů“. Všechny tyto souzvuky je možno chápat 
tónech motivů druhé písně a v její celkové harmonizaci. Zatímco motivy písně Daleko, široko začínají vždy kratšími tóny vyšší hybnosti, zpívané vždy jen částí sboru (pak teprve zazněl dlouhý souzvuk, do něhož vstupovaly imitačním způsobem hlasy, které měly při znějícím dlouhém souzvuku tacet), píseň $\mathrm{Na}$ dole má dlouhé tóny, zpívané celým sborovým tělesem v první části dvoutaktových (event. třítaktových) motivů, a naopak jejich druhou část vyplňují noty kratších hodnot, čímž se velmi zvýší výsledná hybnost. Určitý kontrast celého bloku hudby $\mathrm{B}$ (proti dílu A) lze tedy spatřovat $\mathrm{v}$ určitém zvukovém zahuštění harmonie i faktury.

Závěrečný díl skladby (takty 39-48 a coda 49-54) přináší text a melodické názvuky první písně, u které skladatel zařadil zhudebněný úvodní verš „daleko, široko" až na úplný závěr skladby jako šestitaktovou codu. Celý tento poslední díl skladby, začínající druhým veršem první písně „to ptáča letělo“, je melodicky vyklenutý (vzestup - snad asociace vzletu ptáčete s následující vzpomínkou - melodie s textem „, nedělu večer, podla mña sedělo“?). Ustávání rytmického pohybu přes náznaky bitonality v sekundovém a pak tritonovém vztahu až po závěrečný souzvuk tvořený akordem $G$ dur v mužské složce sboru a Des dur v ženské sopránech, mezzosopránech a altech „rozostřuje“ jasné zvukové kontury celé hudební plochy. ${ }^{24}$ Skladba je tak ukončena $\mathrm{v}$ jisté víceznačnosti, ale přece jen centrálním tónem velké $G \mathrm{v}$ basu jako závěrečnou tečkou.

V celkově výstavbě sboru Daleko, široko převládají v její 1. a 3. části témbrovost a bitonalita (sekundové a tritonové vztahy tónů a akordů), zahuštování a přelévání akordů, a přitom jasná tonalita, halekání a echo efekty (ozvěna) imitace, vysoké a nízké polohy, práce s pianissimem, tardissimo (velmi pomalu a zároveň zajíkavě) a tím je vytvářen dojem jakési „,prostorovosti“. Ve středním dílu naopak zaujme dvojsborovost, opětovné „halekání“ mužských a ženských hlasů ve forte (bitonalita společné s kvartovými akordy na počátku frází). Pomocí kontrastů v „hudebním prostoru“ se autorovi podařilo navodit pocit rozlehlého prostoru mimohudebního.

Poslední část Gurale ${ }^{25}$ navazuje úvodním blokem hudby in $G$ (takty 1-21) na předcházející Daleko, široko. Zvuková masa úvodu narůstá ve velmi pomalém tempu a z pianissima. V mixolydické škále od velkého $G \mathrm{v}$ basu až po $f^{2} \mathrm{v}$ sopránech nastupuje 21 tónů dlouze „držených“ tónů. Tím vzniká jednadvacetitónový diatonický cluster, který přechází do cca 20 sekund trvající aleatorní plochy. Ta je ukončena čtyřmi údery velkého bubnu a poté nástupy „rozptýlených“ motivických jader písně $E j$, gurale, něbičše še v různých polohách: stř̌ední, vysoké, hluboké v $D$ dur (takty 30-62). Přezníváním jednotlivých tónů přes sebe se znovu utváŕejí diatonické clustery, které „rozmazávaji“ kontury jednoduchého, symetricky uspořádaného lidového popěvku. Následuje zlom - prudká změna

funkčně jako zahuštěné $T, S, T D, S$ apod.

25 Pro smíšený sbor (21 hlasů), bicí nástroje (velký buben, claves, dva tom tomy nebo „hra na tělo") a housle ad libitum na goralské motivy. 
tempa $(D=196)$ začínající dvěma zvoláními sólistů a jejich rytmickou imitací dř́viky (nebo houslemi) ${ }^{26}$ Skladba pokračuje v čtyřhlasé sazbě smíšeného sboru, v níž melodie guralského popěvku písně $v G d u r^{27}$ - doprovázená vždy ostatními sborovými hlasy ${ }^{28}$ - přechází z hlasu do hlasu. Objevují se zde variačně prokomponované plochy ${ }^{29}$ (takty 63-137) i další práce s hybností.
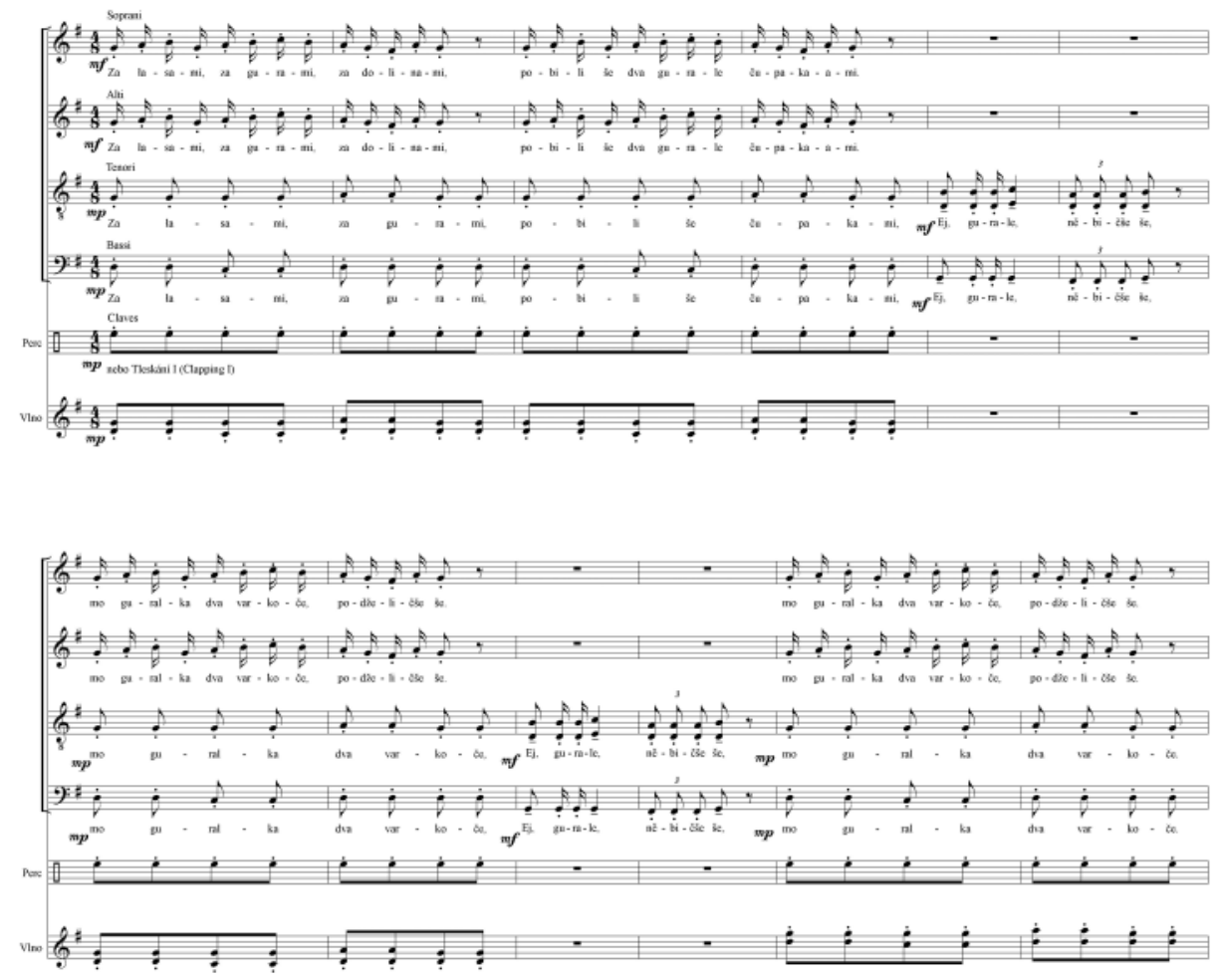

Př. 7 Jan Vičar, Gurale, takty 71-82.

26 O dalších podobách sboru a použitých doprovodných nástrojích skladatel uvedl: „Partituru Gurale jsem v průběhu roku 2006 doplnil a prepracoval i pro jiná sborová obsazení. Zpřesnil jsem úlohu bicich nástrojů a jejich alternativ - luskání prsty, tleskání, plácání na tělo a dupání sboru. [...] Doplnil jsem [...] part virtuózních houslí ad libitum, a to i proto, že snadno přenosné skřipky vždy byly součástí goralské muziky. “ Srovnej VIČAR, Jan. Smišsené sbory (1998-2008). Olomouc: Univerzita Palackého v Olomouci, 2008, s. 136.

27 Od taktu 105 se přeložením melodicko-harmonické podoby celého závěrečného úseku skladby o kvintu výše a do $D$ dur dociluje gradace.

28 Autor předepisuje $\mathrm{v}$ čistých kvartách a kvintách staccata, akcenty a frázovací obloučky a tím usiluje o napodobení instrumentálního doprovodu hudecké muziky v duvajovém rytmu.

29 Zhuštování způsobené kontrakcí motivů $a$ a $b$, zapojování „clusterových“ ploch v menší hybnosti, stejné jaká je na začátku skladby $($ J = 96) v taktech 99-104 a 119-125, a konečně zvyšující se dynamika i celkové zahušt'ování faktury vede k narůstání napětí. 
Při stálém tempu se v tomto bloku hudby zvyšuje napětí, jež vyústí v textové pointě: ,mo guralka vielki serce, podželičše š e“ a v aleatorní ploše recitace od šepotu k výkřikům, kde se dynamická hladina zvyšuje od $\boldsymbol{p}$ do $\boldsymbol{f}$. Následující devítitaktovou plochou, $v$ níž je obsažena zdůvodněná výzva goralům, ,aby se nebili“ (homofonní osmihlas v taktech 142-147, které jsou sice v původním tempu, ale v jiném metru a s velmi pomalou hybností), tríitaktovou codou naopak ve vysoké hybnosti a výkřikem „ej“" skladba končí. ${ }^{30}$

Využitými kompozičními postupy (aleatorní parlanda a výkřiky textu, několikahlasé clustery, střihy melodie na jednotlivé motivy, přeznívání tónů, virtuózní part houslí) jsou Gurale více než pouhou úpravou lidové písně. I když z lidové písně s její jednoduchou hudební strukturou a prostým textem autor vyšel, ve výsledku vytvořil autonomní kompozici, která strhuje emocionalitou a energií, je bravurní a interpretačně náročná. Přitom stejně jako v předcházejících dvou sborech zůstává věrná původní lidové poetice. A to je dalším scelujícím faktorem autorova folklorního sborového triptychu.

Z hlediska jeho makrotektoniky, jak v 1. části Vejr, tak i v části třetí Gurale využil skladatel efektu spočívajícího v enormním zvýšení hybnosti (ta vzrůstá při jednotném tempu až osmkrát) a ve využití perkusivních prvků (tleskání, hra na tělo nebo bicí nástroje a ve Vejru navíc mateníkové změny metrorytmu a metrické posuny dvou rytmických pásem u mužské a ženské složky smíšeného sboru či při tleskání). Kontrastní s krajními částmi je pak Daleko, široko, které je převážně ametrické (volné a místy „zajíkavé“ tardissimo) a kde je dále pracováno s témbrem (sfumato - „rozostřování“ intonace hraničící místy až s mikrointervalikou, s clustery), bitonalitou a imitacemi navozující pocit hudební prostorovosti. $\mathrm{K}$ sevřenosti cyklu přispívají i podobně utvářené barevné úvodní plochy všech trř́ jeho jednotlivých části. Z hlediska mikrotektoniky je nejdůležitější analytická „de-kompozice“ původních folklorních útvarů a následná kompozice získaných motivů s využitím variační techniky.

Tři smíšené sbory, dodatečně a volně spojené v triptych Široko daleko, dobře reprezentují jednu, folklorně zaměřenou linii Vičarových sborových skladeb. Ty jsou v posledních letech českými sbormistry vyhledávané a mají úspěch i u publika.

30 Výstavba závěrečného dílu triptychu je podřízena emocionalitě a základním slovním obrazům textu: kde se událost stala (a), co hrozného se stalo, ( $a$ ), výzva ke zklidnění (b), návrh kompromisního řešení $(a)$. To ostatně uvádí sám autor ve svém komentáři (srovnej s poznámkou č. 25). Sbormistr Milan Motl, který Gurale často uvádí se svým tělesem KOS, sděluje při nácviku sboristům tuto svou představu: „Od chalupy $k$ chalupě se nese zvěst o rvačce dvou horalů (následujicí cca dvacetisekundová parlandová plocha). V̌̌e se pak s nadhledem a lidovému prostředi vlastním humorem vyřeši u muziky a tancovačky (čtyřhlasý sbor v hybném tempu, imitace nástrojového doprovodu a energie goralské muziky). Výzvu goralìm, aby se nebili, zvukově podtrhuje závěr (osmihlasý sbor - ten může být doplněn sebevědomým až furiantským hvizdáním vyjadřujicim nadhled dvou horali nad jejich situací).“ 
Karel Steinmetz (steinmet@pdfnw.upol.cz) je profesorem v oboru Hudební teorie a pedagogika. V letech 1989-2011 působil na Katedře hudební výchovy PdF Univerzity Palackého v Olomouci, nyní je na Katedře HV PdF Ostravské univerzity. Jeho badatelské aktivity jsou zaměřeny na výzkum hudby v regionu střední a severní Moravy se zvláštním zřetelem k hudbě 20. století.

\section{ABSTRACT \\ COMPOSER JAN VIČAR AND ANALYSIS OF HIS FOLKLORE TRIPTYCH FOR MIXED CHOIR ON CZECH, MORAVIAN AND SILE- SIAN FOLK POETRY ŠIROKO DALEKO [FAR AND WIDE]}

Jan Vičar, native of Olomouc $\left({ }^{*} 1949\right)$ belongs to a group of Czech composing music theorists, historians and educators, such as university professors Karel Janeček, Zdeněk Blažek, Karel Risinger, Jaroslav Smolka, Miloš Štědroň and Vladimír Tichý. Also he gained university education in both disciplines - in composition and musicology. Great scope of his interests and abundance of scientific, artistic and organizational activities are the characteristic features of his personality. After studying musicology and the Czech language at the Philosophical Faculty of Palacký University in Olomouc and in parallel accordion at the Conservatory in Ostrava (from both he graduated in 1972), he became a lecturer at the Olomouc Department of Musicology and Music Education with Prof. Robert Smetana.

In preparation for the career of a composer, he continued studying composition at the Janáček Academy of Performing Arts in Brno (with Zdeněk Zouhar, 1976-1978), and at the Academy of Performing Arts in Prague (with Jiří Dvořáček, 1979-1981), which was followed by a post-graduate course in music theory with Karel Risinger (1981-1983). In the mid-eighties he moved from Olomouc to Prague, where he taught music aesthetics at the Academy of Performing Arts and worked for the journal Hudebni rozhledy [Music Review]. At the beginning of the nineties, he contributed to the reopening of the Department of Musicology at Olomouc Philosophical Faculty and became its head. Throughout his career, he divides his creative activities between musicology, university teaching and composing. His work consists of about sixty compositions in all genres of classical music, but the greatest success he achieved in composing for children, female, male and mixed choirs. An analyzed folklore triptych Široko daleko [Far and Wide] on Czech, Moravian and Silesian folk lyrics represents this line of his work.

Key words

Jan Vičar, composition, musicology, analysis

\section{Bibliography - selection}

VIČAR, Jan. Akordeon a jeho hudebni uplatnění. Praha: Panton, 1981.

VIČAR, Jan. Václav Trojan. Praha: Panton, 1989.

VIČAR, Jan. Hudební kritika a popularizace hudby. Praha, 1997.

VIČAR, Jan - PAVLIČÍKOVÁ, Helena - VOŘÍŠEK, Martin. Finale. Učebnice počitačové notace.

Překlad a adaptace amerického originálu David Pogue: Finale. The Art of Music Notation. Vol.

I. Praha, 1997.

VIČAR, Jan - DYKAST, Roman. Hudebni estetika. Praha, 1998.

VIČAR, Jan. Imprints: Essays on Czech Music and Aesthetics. Olomouc-Praha, 2005.

VIČAR, Jan. Szeroko daleko. Tryptyk ludowy na chór mieszany. Przekład Izabela Szulc. 1. Puchacz

-2. Szeroko daleko - 3. Górale. 2012.

VIČAR, Jan. Smišené sbory (1998-2008). Olomouc: Univerzita Palackého v Olomouci, 2008. 